\title{
MARINE IMPACTS IN THE ANTHROPOCENE
}

\section{HERMIT CRABS ASSOCIATED TO THE SHRIMP BOTTOM-TRAWL FISHERY ALONG THE PACIFIC COAST OF COSTA RICA, CENTRAL AMERICA}

\author{
Fresia Villalobos-Rojas ${ }^{1}$, Juan Carlos Azofeifa-Solano ${ }^{1}$, \\ RAQUel Romero-Chaves ${ }^{1}$ and INGO S. WeHRTMANN ${ }^{1,2,3}$ \\ ${ }^{1}$ Unidad de Investigación Pesquera y Acuicultura (UNIP), Centro de Investigación en Ciencias del \\ Mar y Limnología (CIMAR), Universidad de Costa Rica, San José, Costa Rica \\ e-mail: v.fresia@gmail.com \\ ${ }^{2}$ Escuela de Biología, Universidad de Costa Rica, San José, Costa Rica \\ ${ }^{3}$ Museo de Zoología, Escuela de Biología, Universidad de Costa Rica, San José, Costa Rica
}

\begin{abstract}
Studies of the bycatch associated to the shrimp trawling fishery in the Pacific coast of Costa Rica do not assess small organisms $(<10 \mathrm{~cm} \mathrm{TL})$ and non-dominant species $(<0.1 \%$ of total catch). There is a void in assessing the maintenance of the ecology and ecosystem on which the fishery depends. Furthermore, the Constitutional Court of Costa Rica prohibited the renewal of existing and the issuing of new shrimp bottom-trawl licenses, indicating the necessity of more scientific information on the impacts of this fishery. We present the results of a 23-month study of the shrimp bottom-trawl fishery, performed between 50 and $350 \mathrm{~m}$ deep in the Pacific coast of Costa Rica. A total of 109 hermit crabs were collected (six species and two families). Paguristes cf. holmesi was the most common species. Zone II presented the highest species richness and abundance. Most specimens $(81.8 \%)$ were caught in shallower waters (50-149 m). More than $45 \%$ of the trawls presented hermit crabs. It is imperative to further assess the trawling effects on non-commercial benthic fauna and changes on predator-prey relationships, before issuing new shrimp licenses.
\end{abstract}

Key words: Bycatch, benthos, non-dominant species, deep waters, biodiversity.

\section{INTRODUCTION}

Trawling -the dragging of nets across the seabed - can be dated back to 1376 , when concerns and complaints were raised by fishermen about the use of beam trawling ('a new destructive and wasteful fishing habit') in England (Roberts 2007). Since then, the introduction of steamed vessels and otter trawls has evolved in the adaptation of trawl fishing technology of many species (Gillett 2008). Furthermore, technological development, market demands and overexploitation of shallow water fishing grounds have led the fishing fleet to progressively explore into deeper waters causing the deep water ecosystems to face great threats (Roberts 2002; Morato et al. 2006; Ramírez-Llodra et al. 2011; Norse et al. 2012).

Shrimp fisheries have used many types of gears (beach seines, lift nets, cast nets, tramps, etc.), but the otter trawl is currently the most important commercial gear worldwide (Gillett 2008). In recent decades, the concern over the bycatch of the shrimp trawling fisheries has increased significantly (Dumont and D'Incao 2011; Queirolo et al. 2011; Meltzer et al. 2012; Arana et al. 2013; Villalobos-Rojas et al. 2017; Clarke et al. 2018), and the discard rates of these fisheries has 
increased significantly (Kelleher 2005; Arana et al. 2013). Moreover, information voids on the biology of both target and non-target species preclude any solid conclusions about the impacts of these fisheries (Bensch et al. 2008; Polidoro et al. 2008; Soykan et al. 2008). Deep water fisheries in Latin America focus mainly on benthic and demersal invertebrates (Arana et al. 2009; Wehrtmann et al. 2012). Detailed information on the composition of shrimp bottom-trawl fisheries' catch in the region is limited to the Chilean nylon shrimp fishery (Heterocarpus reedi Bahamonde, 1955), and the northern nylon shrimp (Heterocarpus vicarius Faxon, 1893) and kolibri shrimp (Solenocera agassizii Faxon, 1893) in Central America and Colombia (Chile: Queirolo et al. 2011; Arana et al. 2013, Colombia: Puentes et al. 2007, Costa Rica: Wehrtmann and Echeverría-Sáenz 2007; Arana et al. 2013; Villalobos-Rojas et al. 2017). Nevertheless, little attention has been paid to hermit crabs caught as bycatch in these fisheries. Puentes et al. (2007) reported Xylopagurus cancellarius Walton, 1950, as part of the bycatch of the trawling fishery from the Colombian Pacific, while Wehrtmann and Echeverría-Sáenz (2007) mentioned two species of hermit crabs from shrimp trawls along the Costa Rican Pacific: Paguristes bakeri Holmes, 1900 and Petrochirus californiensis Bouvier, 1895.

The Costa Rican Pacific waters support a high biodiversity of hermit crabs, comprising currently four families and 34 species (Vargas and Wehrtmann 2009), with 19 of these species reported from waters deeper than $50 \mathrm{~m}$ (Vargas and Wehrtmann 2009). Hermit crab taxonomy is presently under review, and a large number of new species have been recently described while others have been re-described for the Eastern Tropical Pacific (Ayón-Parente and Madrid-Vera 2009; Ayón-Parente and Hendrickx 2012a, 2012b, 2013; AyónParente and Wehrtmann 2019). Shrimp bottomtrawl fisheries, thus, represent an excellent opportunity to access biological material from deep waters $(>50 \mathrm{~m})$, especially in countries like Costa
Rica, which do not have research vessels. The collected information allows expanding the description of the hermit crab diversity and distribution patterns along the Costa Rican Pacific continental shelf (Wehrtmann and NielsenMuñoz 2009; Wehrtmann et al. 2012; Ayón-Parente and Wehrtmann 2019).

In 2013, the constitutional court of Costa Rica prohibited both the renewal of existing and the issuing of new shrimp bottom-trawl licenses, indicating the necessity of more scientific information on the impacts of this fishery (Sentencia No 2013-10540 2013). In order to assess the possible impacts of shrimp trawling on the ecosystem, it is imperative to gather information on the diversity and ecological patterns of deep water species, including the hermit crabs. Therefore, the results of this study provide information necessary for the development of management approaches aimed to secure the sustainability of these deep water resources.

\section{MATERIALS AND METHODS}

Specimens were collected during a 23-month period (March 2010-February 2012) along the Costa Rican Pacific continental shelf. The sampling was carried out as part of a project to study the fisheries of commercially important deepwater shrimps ( $H$. vicarius and $S$. agassizii). Samples were obtained using commercial shrimp trawlers (22.5 m long, $270 \mathrm{HP}$ ) equipped with two standard epibenthic nets $(20.5 \mathrm{~m}$ length, mouth opening 5.35 width $\times 0.85 \mathrm{~m}$ height, mesh size $4.5 \mathrm{~cm}$, cod-end mesh size $3.0 \mathrm{~cm}$ ), at a speed of 2.0 knots $\left(\sim 3.7 \mathrm{~km} \cdot \mathrm{h}^{-1}\right)$. The specimens were collected in the framework of scientific sampling programs along the entire Pacific coast of Costa Rica with samples collected between 50 and 300 $\mathrm{m}$, with a total of 179 samples (44.75 h) (Figure $1)$. The study area was divided into three geographic zones based on oceanographic conditions 
to analyze the geographic distribution of hermit crabs captured by the shrimp bottom-trawl fishery: Zone I, influenced by a seasonal upwelling in the northern Pacific coast; Zone II, Golfo de Nicoya estuarine system, Central Pacific and Térraba-Sierpe estuarine system; and Zone III, mouth of Golfo Dulce, a tropical fjord with anoxic conditions (Nielsen-Muñoz and QuesadaAlpízar 2006; Cortés and Wehrtmann 2009) (Figure 1). The bathymetric distribution was divided into four depth ranges: 50-99 m, 100-149 m; 150 $199 \mathrm{~m}$, and 200-350 m. The collected hermit crabs were stored on board at $0{ }^{\circ} \mathrm{C}$ and subsequently transported to the laboratory. All specimens were identified to species level using the available literature (Ball and Haig 1974; McLaughlin 1981a, 1981b, 1982; Lemaitre 1989; Hendrickx 1995; Lemaitre and McLaughlin 1996; Hendrickx and Harvey 1999; Ayón-Parente 2009; Ayón-Parente and Hendrickx 2010; McLaughlin et al. 2010), preserved in $70 \%$ ethanol and deposited in the collection of the Museo de Zoología of the Universidad de Costa Rica (MZUCR).

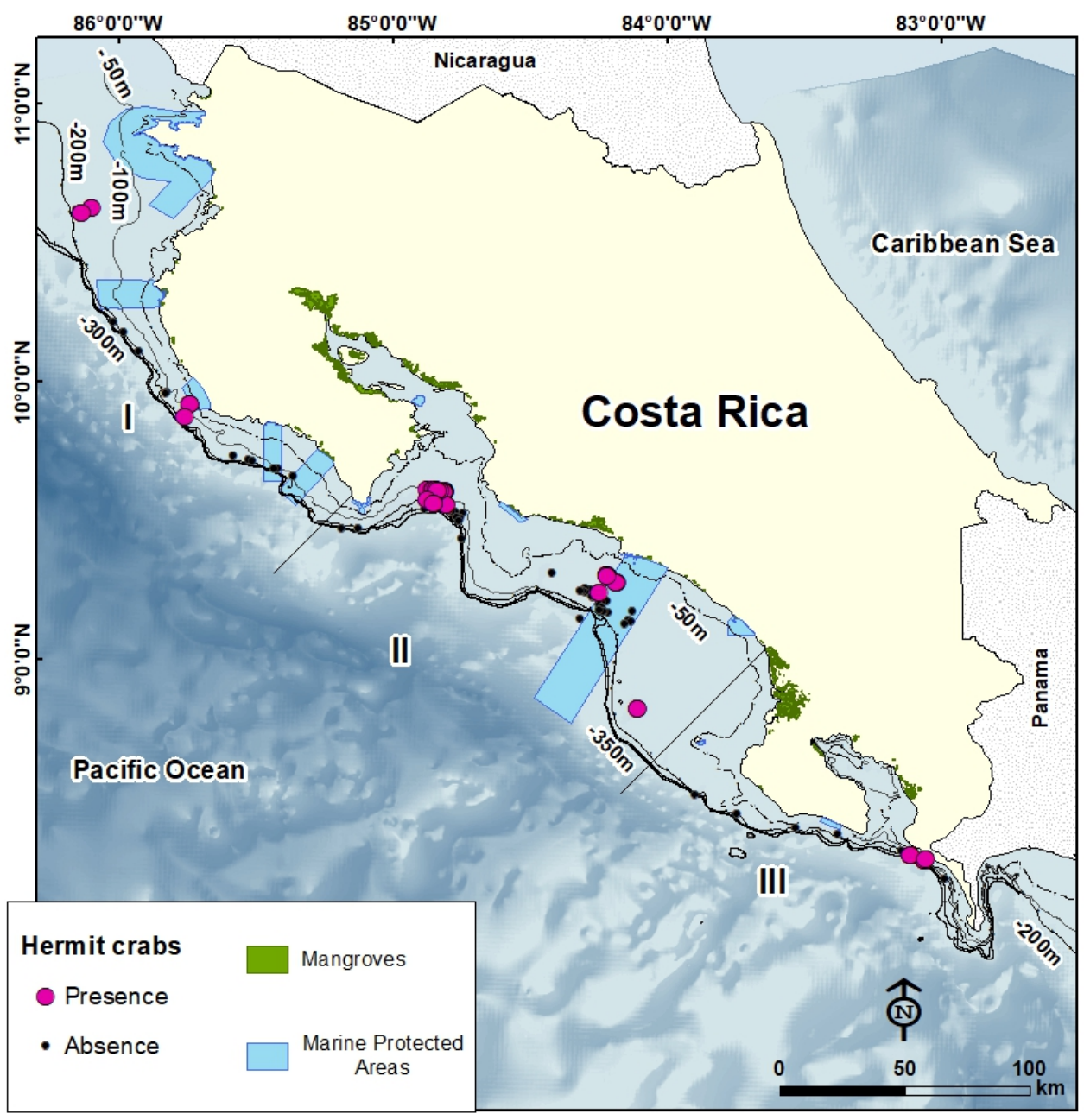

Figure 1. Pacific coast of Costa Rica, Central America, divided into the three zones used in the analyses. The sampling stations indicate the presence (pink circle) or absence (small black circle) of hermit crabs in the bycatch. 


\section{Species composition}

To compile a species list of hermit crabs we examined both the living specimens collected during our surveys (2010-2012) as well as additionally specimens collected at the same fishing grounds and depths during other shrimp bottomtrawl surveys carried out between 2008 and 2012 with the same methodology. A species accumulation curve was calculated to assess the completeness of the sampling methods used to record the hermit crabs inhabiting the surveyed area (20102012), using the 'vegan' library (Oksanen et al. 2016) in the R statistical package v3.1.3.

\section{Morphometric measurements}

The cephalothorax length (CL), abdomen length (AL) and total length (TL $=\mathrm{CL}+\mathrm{AL})$ of hermit crabs were measured using a caliper ( \pm $0.05 \mathrm{~mm}$ ) (Figure 2). Additionally, each specimen was weighted $( \pm 0.001 \mathrm{~g})$ and sexed using the location of gonopores at the base of the third (females) or fifth (males) pereiopods (Hendrickx 1995; Hendrickx and Harvey 1999). Photographs of at least one specimen per species were taken with a Canon EOS7D camera equipped with macro lens Canon EF $100 \mathrm{~mm}$ and lens Canon MP-E $65 \mathrm{~mm}$. A Chi-square goodness of fit test

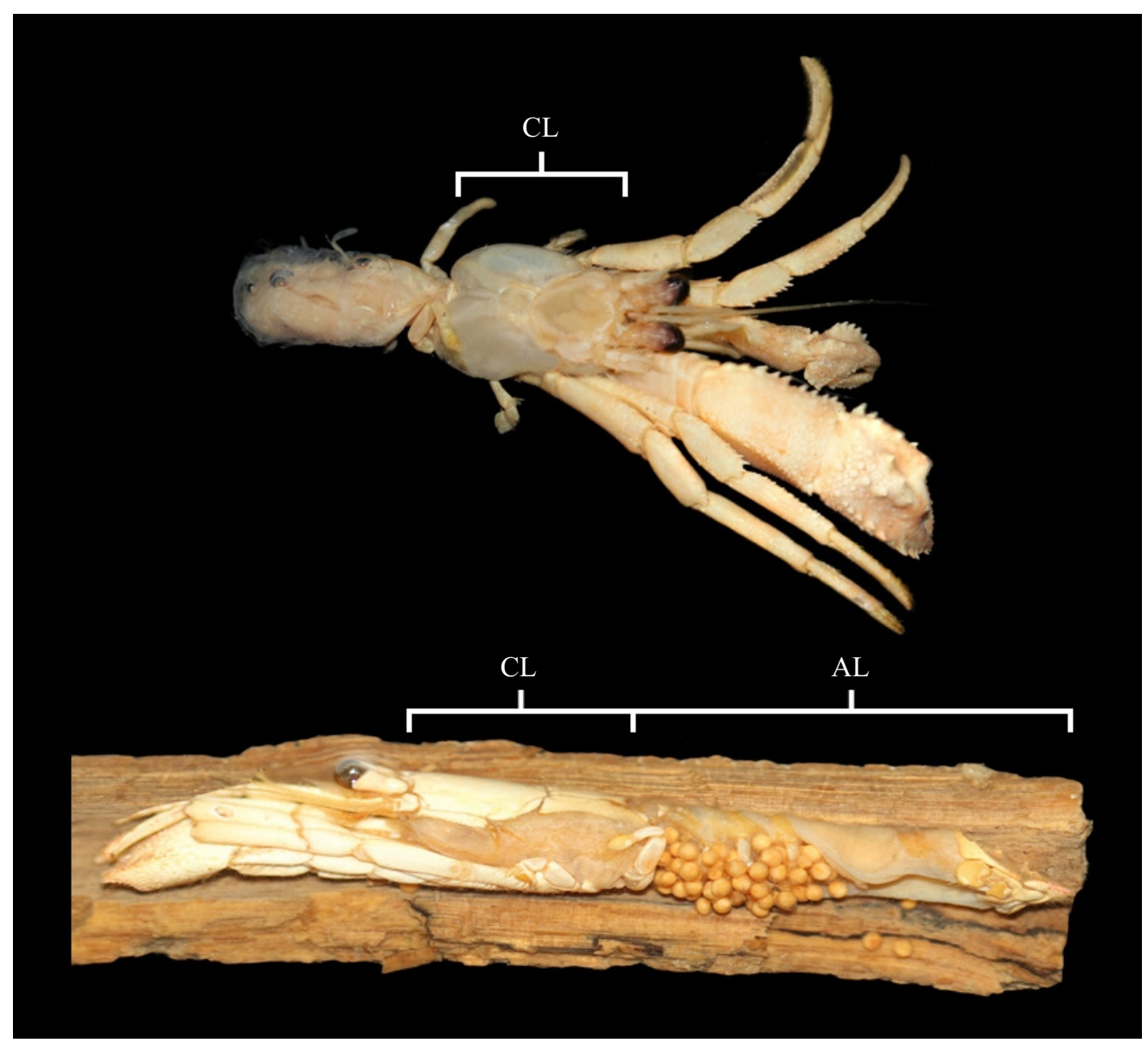

Figure 2. Measurements recorded for hermit crabs collected along the Pacific coast of Costa Rica. CL: carapace length, AL: abdomen length. 
was conducted to detect species with sex ratios, which were different from the expected 1:1 ratio (Zar 1999; Hernáez et al. 2012; Villalobos-Rojas and Wehrtmann 2018).

\section{Species geographic and bathymetric distribu- tion}

We used a Generalized Linear Model (GLM) with binomial distribution to identify environmental variables influencing the presence/ absence of hermit crabs. Seven independent variables were considered for the analysis: (1) geographic zones (I, II, III), (2) depth level (50-99 m, 100-149 m, 150-199 m and > $200 \mathrm{~m}$ ), (3) seasonality (rainy, transition and dry season; according to Amador et al. 2006), (4) Oceanic Niño Index (ONI categories: cold, normal and warm; NWSCPC 2019), (5) marine bottom substrate (bathyal soft-bottoms, infralittoral hard-bottom and sublittoral lithoclastic mud) as provided by TNC (2008) (6) shortest distance to the closest protected area and mangrove area and (7) sea bottom slope. The shortest distance to the closest protected area and mangrove area were obtained with spatial data from ITCR (2014) and the tool 'Near' of the Analysis toolbox, while sea slope bottom data were obtained using the Digital Elevation Model (DEM) for the Eastern Tropical Pacific (TNC 2008) and the tool 'Slope' of the 3D Analyst toolbox. Slope values for each record were extracted using the tool 'Extract multivalues to points' from Spatial Analyst toolbox. The GIS and all toolboxes used are part of ArcGIS10.4 (ESRI 2019).

Statistical analyses were performed using the 'coin' package (Hothorn et al. 2006) in R v3.1.3. A Tukey post-hoc test was applied to determine differences considering the categorical environmental variables that were significant in the binomial-GLM using the 'multcomp' package (Hothorn et al. 2008).

\section{RESULTS}

\section{Species composition}

A total of 109 specimens were collected, comprising six species, five genera and two families (Table 1; Figure 3). The most common species was Paguristes cf. holmesi Glassell, 1937 ( $\mathrm{n}=$ 63), followed by Areopaguristes praedator (Glassell, 1937) and Tomopagurus merimaculosus (Glassell, 1937) with 15 specimens each (Table 1). Dardanus nudus Ayón-Parente and Hendrickx, 2009 and D. stimpsoni Ayón Parente and Hendrickx, 2009 were collected only during the additional surveys (between 2008 and 2012) (Table 1). Both D. nudus and D. stimpsoni are new reports for Costa Rica. Figure 4 shows the species accumulation curve with a relatively low slope and Figure 5 presents the locality of all hermit crabs analyzed.

\section{Morphometric measurements}

Table 2 summarizes morphometric measurements obtained from the 109 specimens collected. The largest specimen belonged to D. stimpsoni with $83.0 \mathrm{~mm}$ TL (29.4 mm CL), whereas in average $D$. nudus presented the largest length $(62.6 \pm 12.7 \mathrm{~mm}$ TL). The smallest specimen was represented by $P$. cf. holmesi with a total length of $11.7 \mathrm{~mm}$ ( $8.4 \mathrm{~mm} \mathrm{CL})$, whereas in average $A$. praedator comprised the smallest specimens $(25.3 \pm 5.2 \mathrm{~mm} \mathrm{TL})$ (Table 2).

\section{Species geographic and bathymetric distribu- tion}

A total of 189 shrimp bottom-trawl surveys were carried out between 2010 and 2012 (Table $3)$. The Zone II presented the highest sampling effort $(32.75 \mathrm{~h})$, with the highest species richness (four) and abundance $(\mathrm{n}=60)$. In all zones, more 
Table 1. Species list, number of collected specimens (n), geographic distribution and depth range (m) reported in literature compared to the depth range for the hermit crabs collected as bycatch in the shrimp bottom-trawl fishery along the Costa Rican Pacific (2008-2012).

\begin{tabular}{|c|c|c|c|c|}
\hline Species & $\mathrm{n}$ & Geographic distribution & $\begin{array}{l}\text { Previously } \\
\text { reported depth } \\
\text { range }(\mathrm{m})\end{array}$ & $\begin{array}{l}\text { Study depth } \\
\text { range }(\mathrm{m})\end{array}$ \\
\hline
\end{tabular}

Diogenidae

Areopaguristes praedator

(Glassell 1937)

Dardanus nudus*

15 Gulf of California to Costa Rica ${ }^{6} \quad 6-155^{6}$

$93.5-158.9$

Ayón Parente and Hendrickx (2009)

Dardanus stimpsoni ${ }^{*}, \dagger, \ddagger$

4 Gulf of California-Panamic Region ${ }^{4} \quad 16-55^{4} \quad 41.1-56.1$

Ayón Parente and Hendrickx (2009)

Paguristes cf. holmesi ${ }^{*}, \dagger, \ddagger$

10 Gulf of California ${ }^{4, \dagger}$

$2-144^{4}$

$187 *$

Glassell 1937

63 Gulf of California ${ }^{5, \dagger}$

$60-150^{5}$

$84.1-187$

Paguridae

Tomopagurus merimaculosus

15 Gulf of California to Colombia ${ }^{2,3} \quad 35-183^{2,3}$

$67.3-187$

(Glassell 1937)

Xylopagurus cancellarius

Walton 1950

2 Costa Rica and Colombia ${ }^{1,2,3}$

$73^{1,2,3}$

$93.5^{+}$

Total specimens

\footnotetext{
* New report for Costa Rica.

†Geographic distribution extension.

tDepth range extension.

${ }^{1}$ Lemaitre (1995).

${ }^{2}$ Vargas and Cortés (2004).

${ }^{3}$ Vargas and Wehrtmann (2009).

${ }^{4}$ Ayón-Parente and Hendrickx (2009).

${ }^{5}$ Ayón-Parente and Hendrickx (2010).

${ }^{6}$ Ayón-Parente et al. (2015).
}

than $45 \%$ of the trawls presented at least one species of hermit crab. Only Paguristes cf. holmesi was collected in all three sampling areas.

Most of the specimens (81.8\%) were caught in the first two depth levels (50-99 $\mathrm{m}$ and 100-149 m). The 50-99 m depth level had the highest sampling effort $(15.3 \mathrm{~h})$, the highest percentage of samples with hermit crabs $(90.2 \%)$, the highest species richness (four), and the highest abundance $(n=55)$. On the other hand, the 150-199 $\mathrm{m}$ depth level had the second highest sampling effort $(12.8 \mathrm{~h})$, but less than $40 \%$ of the samples contained hermit crabs. The 100-149 and $>200 \mathrm{~m}$ depth levels had similar sampling efforts (7.8 $\mathrm{h}$ and $9 \mathrm{~h}$ ); nevertheless, hermit crabs were absent at the deepest level. Tomopagurus meri- 


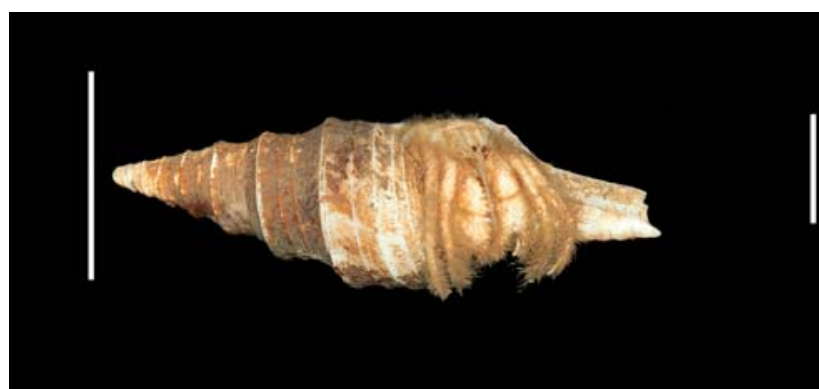

A

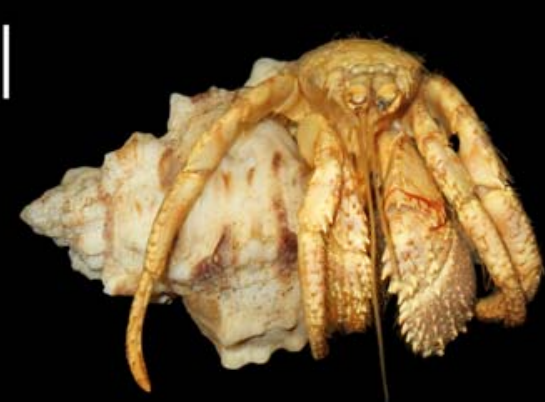

$\mathrm{C}$

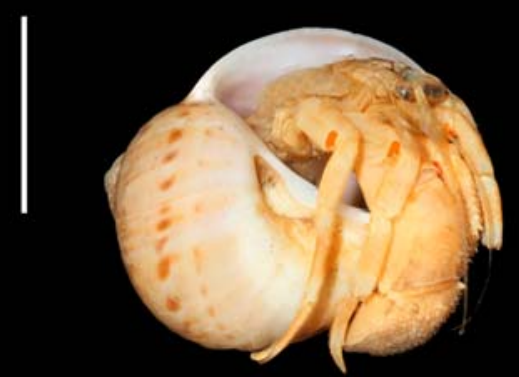

$\mathrm{E}$

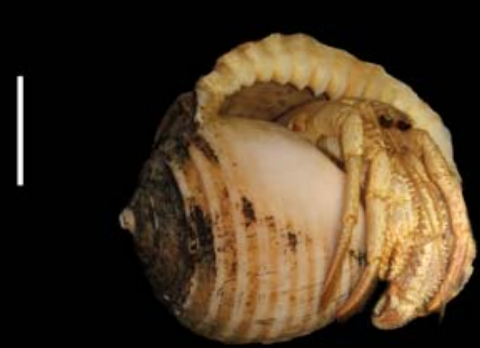

B

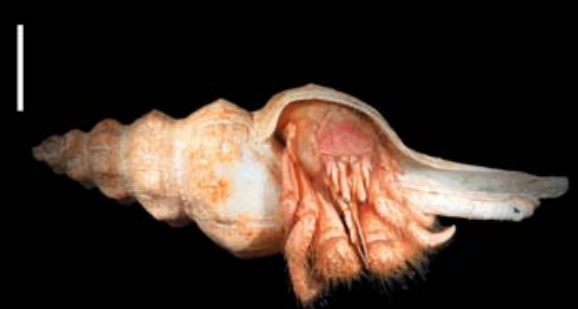

$\mathrm{D}$

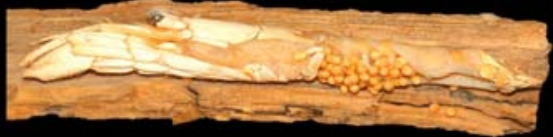

$\mathrm{F}$

Figure 3. Hermit crabs collected as bycatch in the shrimp bottom-trawl fishery along the Costa Rican Pacific. Diogenidae. A) Areopaguristes praedator, $9.95 \mathrm{~mm}$ CL (MZUCR 3594-1). B) Dardanus nudus, $25.0 \mathrm{~mm}$ CL (MZUCR 3537). C) Dardanus stimpsoni, $20.5 \mathrm{~mm}$ CL (MZUCR 3595-1). D) Paguristes cf. holmesi, $19.0 \mathrm{~mm}$ CL (MZUCR 3593-1). Paguridae. E) Tomopagurus merimaculosus, 10.0 mm CL (MZUCR 3595-2). F) Xylopagurus cancellarius, $20.3 \mathrm{~mm}$ CL (MZUCR 3596-1). Scale bars $=10 \mathrm{~mm}$.

maculosus presented the widest depth distribution range (67-187 m), whereas Xylopagurus cancellarius occurred only at $93.5 \mathrm{~m}$ depth (Table 1).

The results from the binomial-GLM selected five variables that significantly influenced $(p<$
$0.05)$ the presence of hermit crabs: (1) depth level, (2) ONI categories, (3) marine bottom substrate (4) sea bottom slope, and (5) geographic coordinates. The GLM (hermit crab presence $\sim$ depth + $\mathrm{ONI}+$ marine bottom substrate + sea bottom slope 


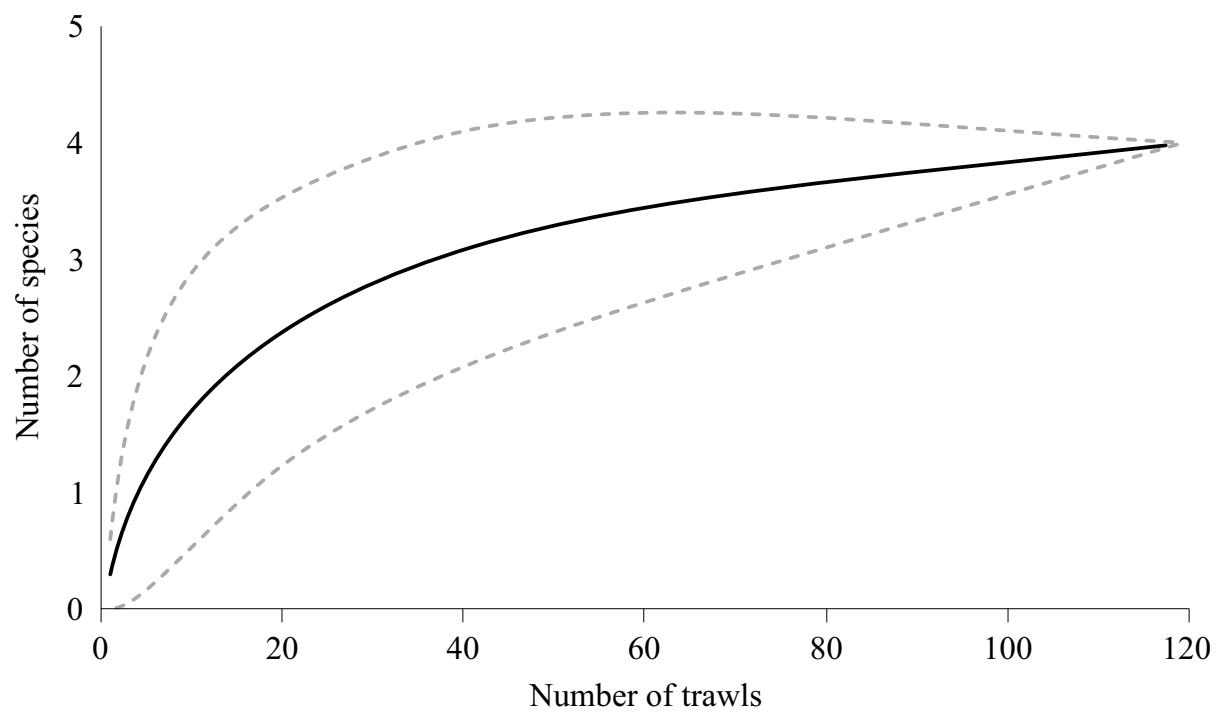

Figure 4. Number of hermit crab species accumulated by number of shrimp bottom-trawls carried out between 2010 and 2012 along the Pacific coast of Costa Rica, Central America.

+ geographic coordinates) explained $72.4 \%$ of the observed variance. Additionally, the Tukey posthoc test revealed significant differences between the factors of the categorical variables according to the probability of presence of hermit crabs: depth level (50-99 m > 100-149 m, 150-199 $\mathrm{m}$ and $>200 \mathrm{~m}, \mathrm{p}<0.01$ ), marine bottom substrate (lithoclastic mud $>$ bathyal soft-bottoms; $\mathrm{p}<0.01$ ) and ONI categories (cold $>$ normal). Although no significant differences were detected between the geographic zones (I, II and III), a significant tendency to find more hermit crabs in higher longitudes was determined $(\mathrm{p}>0.05)$ Table 4.

\section{DISCUSSION}

The hermit crab fauna from the Costa Rican Pacific is currently comprised by 34 species; including the two new records obtained by the present study (Dardanus nudus and D. stimpsoni: 1 sp. of Coenobitidae, 14 spp. of Diogenidae, 17 spp. of Paguridae and 2 spp. of Parapaguridae). Nineteen of these species are distributed deeper than $50 \mathrm{~m}: 7 \mathrm{spp}$. of Diogenidae, $10 \mathrm{spp}$. of Paguridae, and 2 spp. of Parapaguridae (Vargas and Cortés 2004, Vargas and Wehrtmann 2009). The six species found in our study represent $31.6 \%$ of hermit crabs fauna reported at these depths.

Published information on the hermit crabs associated to the Costa Rican shrimp bottomtrawl fisheries is scarce. Campos (1986) reported 'crustaceans in gastropod shells' representing $0.0006 \%$ of total capture of shrimp trawls between $27 \mathrm{~m}$ and $238 \mathrm{~m}$ deep, but no species identification was provided. Wehrtmann and Echeverría-Sáenz (2007) reported Paguristes bakeri as rare ( $<15 \%$ of hauls) and Petrochirus californiensis as occasional (15\% of hauls) fauna in the northern nylon shrimp (Heterocarpus vicarius) fisheries of Costa Rica, collected at $273 \mathrm{~m}$ and $293 \mathrm{~m}$ deep, respectively. Therefore, there are a total of seven hermit crab species associated to the Costa Rican shrimp fisheries since the $P$. bakeri found by Wehrtmann and EcheverríaSáenz (2007) is probably P. holmesi found and identified in our study.

All six species found in our study were previously documented for the Panamic Region 


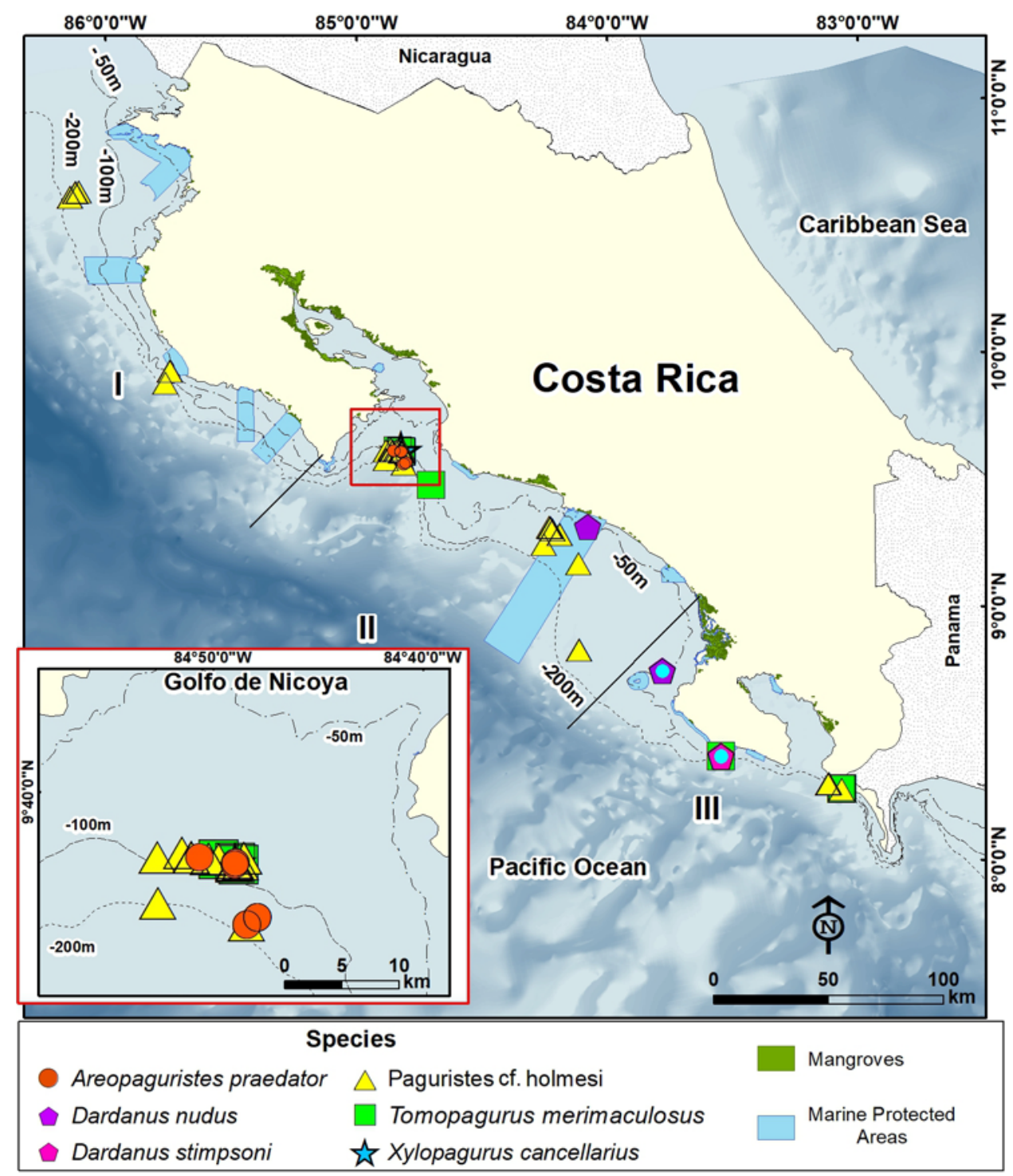

Figure 5. Presence of hermit crab species associated to the shrimp bottom-trawl fishery from 2010 to 2012 along the Pacific coast of Costa Rica, Central America. The close-up shows the distribution of hermit crab species collected in the entrance of the Golfo de Nicoya.

(Ayón-Parente and Hendrickx 2010). Nevertheless, here we present the first report of two hermit crab species: Dardanus nudus and Dardanus stimpsoni for the Costa Rican Pacific. Our records expand the depth range for D. stimpsoni down to $187 \mathrm{~m}$ (both were previously reported at 144 m) (Ayón-Parente and Hendrickx 2010). Three of the other collected species have been previously reported: Areopaguristes praedator, Tomopagurus merimaculosus, and Xylopagurus cancellarius (see Lemaitre 1995; Vargas and Cortés 2004; Vargas and Wehrtmann 2009; AyónParente et al. 2010, 2015). Nevertheless, our data extend the depth range for $X$. cancellarius from $73.1 \mathrm{~m}$ deep (Vargas and Wehrtmann 2009) down to $93.5 \mathrm{~m}$. 
Table 2. Measurements and sex ratio of hermit crabs collected as bycatch in the shrimp bottom-trawl fishery along the Costa Rican Pacific (2008-2012). SD: standard deviation, n: number of specimens analyzed, F: females, M: males.

\begin{tabular}{cccccc}
\hline Species & $\mathrm{n} \quad \begin{array}{c}\text { Sex ratio } \\
(\mathrm{F} / \mathrm{M})\end{array}$ & Mean $\pm \mathrm{SD}$ Range & Mean $\pm \mathrm{SD}$ Range & Mean \pm SD Range \\
\hline
\end{tabular}

Diogenidae

\begin{tabular}{|c|c|c|c|c|c|c|c|c|}
\hline $\begin{array}{l}\text { Areopaguristes praedator } \\
\text { (Glassell 1937) }\end{array}$ & 15 & 0.9 & $8.13 \pm 1.6$ & $5.6-10.5$ & $25.3 \pm 5.2$ & $15.45-32.1$ & $0.43 \pm 0.3$ & $0.1-0.9$ \\
\hline $\begin{array}{l}\text { Dardanus nudus } \\
\text { Ayón-Parente and } \\
\text { Hendrickx (2009) }\end{array}$ & 4 & 0.0 & $20.9 \pm 4.0$ & $16.0-25.6$ & $62.6 \pm 12.7$ & $48.7-79.2$ & $8.4 \pm 4.8$ & $4.69-15.1$ \\
\hline $\begin{array}{l}\text { Dardanus stimpsoni } \\
\text { Ayón-Parente } \\
\text { Hendrickx (2009) }\end{array}$ & 10 & 0.6 & $16.1 \pm 5.6$ & $9.8-29.4$ & $47.6 \pm 14.6$ & $29.8-83.0$ & $4.0 \pm 4.8$ & $0.4-16.7$ \\
\hline $\begin{array}{l}\text { Paguristes cf. holmesi } \\
\text { Glassell } 1937\end{array}$ & 63 & $0.4^{*}$ & $15.3 \pm 3.8$ & $8.4-25.6$ & $43.6 \pm 12.6$ & $11.7-75.7$ & $3.19 \pm 2.5$ & $0.2-11.8$ \\
\hline Paguridae & & & & & & & & \\
\hline $\begin{array}{l}\text { Tomopagurus } \\
\text { merimaculosus } \\
\text { (Glassell 1937) }\end{array}$ & 15 & $0.3^{*}$ & $13.6 \pm 2.4$ & $9.65-18.55$ & $36.8 \pm 6.7$ & $12.15-50.2$ & $2.3 \pm 1.3$ & $0.9-55.9$ \\
\hline $\begin{array}{l}\text { Xylopagurus cancellarius } \\
\text { Walton } 1950\end{array}$ & 2 & 1.0 & $17.3 \pm 4.2$ & $14.3-20.3$ & $52.7 \pm 19.1$ & $39.2-66.2$ & $3.0 \pm 2.7$ & $1.1-4.9$ \\
\hline
\end{tabular}

The specimens of Paguristes cf. holmesi were identified as confer because its taxonomy is still under revision in the Eastern Tropical Pacific (M. Ayón-Parente, pers. comm). This species was previously synonymized with Paguristes bakeri Holmes, 1900 (Haig and Hopkins 1970). Afterwards, Moran and Dittel (1993) reported specimens of $P$. holmesi from material collected in Costa Rica. Nevertheless, Hendrickx and Harvey (1996) indicated that the material mentioned by Moran and Dittel (1993) could not be located in the Los Angeles County Museum of Natural History where it was allegedly deposited. Recently, Ayón-Parente (2009) examined additional materi- al from the Mexican Pacific and found enough morphological differences for them to be considered as a separate species. Consequently, it is possible that the species identified as Paguristes bakeri by Wehrtmann and Echeve-rría-Sáenz (2007) is Paguristes cf. holmesi. Therefore, our study reports five additional species associated to shrimp bottom-trawl fisheries to the previous study (Wehrtmann and Echeverría-Sáenz 2007).

Regarding the geographic distribution of the species, results indicated a tendency to find more hermit crabs in higher longitudes. For example, although Zones I and III had similar sampling efforts, higher abundance was found in Zone I. 
Table 3. Number of species, number of individuals, percentage of samples with hermit crab, and total number of samples by geographical area and depth range associated with shrimp bottom-trawl fisheries along the Costa Rican Pacific (2010-2012).

\begin{tabular}{|c|c|c|c|c|c|c|c|}
\hline \multirow[b]{2}{*}{ Species } & \multicolumn{3}{|c|}{ Geographic area } & \multicolumn{4}{|c|}{ Depth range $(\mathrm{m})$} \\
\hline & I & II & III & $50-99$ & $100-149$ & 150-199 & $>200$ \\
\hline \multicolumn{8}{|l|}{ Diogenidae } \\
\hline Areopaguristes praedator & - & 15 & - & 8 & 5 & 2 & - \\
\hline Paguristes cf. holmesi & 9 & 40 & 10 & 39 & 6 & 14 & - \\
\hline \multicolumn{8}{|l|}{ Paguridae } \\
\hline Tomopagurus merimaculosus & 9 & 3 & - & 6 & 6 & - & - \\
\hline Xylopagurus cancellarius & - & 2 & - & 2 & - & - & - \\
\hline Number of specimens & 18 & 60 & 10 & 55 & 17 & 16 & 0 \\
\hline Number of species & 2 & 4 & 1 & 4 & 3 & 2 & 0 \\
\hline Samples with hermit crabs (\%) & 69.2 & 45.8 & 45.5 & 90.2 & 54.8 & 31.4 & 0 \\
\hline Number of samples & 26 & 131 & 22 & 61 & 31 & 51 & 36 \\
\hline Sampling effort (h) & 6.5 & 32.75 & 5.5 & 15.3 & 7.8 & 12.8 & 9 \\
\hline
\end{tabular}

Nevertheless, additional studies with a higher sampling effort are required to confirm this tendency.

Our results suggest that the probability of finding hermit crabs is higher at shallower waters (50-99 $\mathrm{m})$ and decreases towards deeper waters $(>200 \mathrm{~m})$. A similar pattern was observed for hermit crabs of the family Diogenidae in the Eastern Pacific, where the species richness was highest at shallower waters (Ayón-Parente and Hendrickx 2010). Our results follow the general distribution pattern of marine benthic invertebrates (Sanders 1963). Therefore, shrimp fisheries carried out in shallower waters $(<100 \mathrm{~m})$ will have a greater impact on the hermit crab community than deep-water shrimp fisheries. In Costa Rica, the shallow-water shrimp fishery has focused on seven Penaeidae species (Litopenaeus vannamei, L. stylirostris, L. occidentalis, Xiphopenaeus riveti, Trachypenaeus byrdii, Farfantepenaeus brevirostris, and F. californiensis) and was carried out between 5 and $120 \mathrm{~m}$ deep (Álvarez and Salazar 2010). In the case of the trawling shrimp fisheries will be reinstalled in Costa Rica, the monitoring program should include identifying hermit crab species.

The probability of finding hermit crabs off the Costa Rican Pacific is higher during cold Oceanic Niño Index (ONI) than during normal ONI conditions Hermit crabs are affected in different ways by temperature changes (Briffa et al. 2013; Gilland 2017). For example, Gilland (2017) suggested that changes in temperature levels affect the ability of tide pool hermit crabs to occupy high quality shells that will protect them from predators and desiccation, as well as decrease growth rate and increase energy usage. To our knowledge there are no studies associating deep water hermit crabs with temperature, however, our results suggest that temperature could be affecting their distribution, which might be important considering the different climate change scenarios (Gorman et al. 2018).

In our study, hermit crabs were caught on soft bottom sediments (lithoclastic mud and bathyal 
Table 4. Generalized Linear Model for the presence of hermit crabs associated with shrimp bottom-trawl fisheries along the Costa Rican Pacific (2010-2012).

\begin{tabular}{lcccl}
\hline Coefficients & Estimate & Standard error & $\mathrm{z}$ & $\operatorname{Pr}(>|\mathrm{z}|)$ \\
\hline (Intercept) & 296.3248 & 857.9968 & 0.345 & 0.729818 \\
Depth 100 & 2.8904 & 0.7457 & -3.878 & $0.000225^{*}$ \\
Depth 150 & -2.8904 & 0.7349 & -4.439 & $0.000252^{*}$ \\
Depth 200 & -20.847 & 2467.13 & -0.008 & 0.992546 \\
Depth 250 & -20.847 & 3400.71 & -0.006 & 0.994615 \\
Depth 300 & -20.847 & 5377 & -0.004 & 0.996911 \\
Latitude & -68.0098 & 51.0083 & -1.33 & 0.1824 \\
Longitude & 12.6376 & 6.5037 & 1.943 & $0.049^{*}$ \\
Latitude $\times$ Longitude & -0.8824 & 0.6107 & -1.445 & 0.1485 \\
ONI cold category & $-1.61 \mathrm{E}+00$ & $7.62 \mathrm{E}-01$ & -2.113 & $0.0346^{*}$ \\
ONI normal category & $-1.34 \mathrm{E}-01$ & $8.76 \mathrm{E}-01$ & -0.152 & 0.8789 \\
Sea bottom slope & $-1.56 \mathrm{E}+00$ & $3.99 \mathrm{E}-01$ & -3.921 & $0.0000884^{*}$ \\
Marine bottom substrate & 1.5444 & 0.6524 & 2.367 & $0.0179^{*}$ \\
\hline
\end{tabular}

$* \mathrm{p}<0.05$.

GLM (hermit crab presence $\sim$ depth + ONI + marine bottom substrate + sea bottom slope + geographic coordinates, family $=$ binomial, link $=$ logit).

Null deviance: 121.901 on 112 degrees of freedom.

Residual deviance: 33.679 on 85 degrees of freedom.

AIC: 89.679 .

soft-bottoms), due to the characteristics of commercial shrimp trawling. Most hermit crabs were captured in trawls taken on the lithoclastic mud bottom, which were covered by fine grain to very fine sediments (SINAC 2008). Sediment particle size (Stanski et al. 2016) and sediment organicmatter content (Fransozo et al. 1998; Frameschi et al. 2014; Stanski et al. 2016) has been correlated to the abundance species of hermit crabs.

\section{Impact of shrimp trawling fisheries}

Few studies assessing the fauna associated to bottom-trawl shrimp fisheries have considered its impacts on small and non-dominant species $(<$ $0.1 \%$ of total catch) (Branco et al. 2015; Villalobos-Rojas et al. 2017). In fact, hermit crabs have been rarely identified when monitoring the bycatch present in shrimp bottom-trawl fisheries (Branco et al. 2015; Gimenez-Hurtado et al. 2016). Non-dominant species, however, can have important ecological functions in the community. For example, hermit crabs have been reported as important allogenic ecosystem engineers in marine habitats and to have a large number of symbiotic relationships (Gutierrez and McDermott 2004; Pretterebner et al. 2012).

The impact of shrimp trawling on hermit crabs has been poorly studied (Ramsay et al. 1996; Groenewold and Fonds 2000; Stanski et al. 2016). Ramsay et al. (1996) suggested that some scavenging hermit crabs could migrate to recently trawled areas to feed on the damaged or disturbed fauna affected by trawling. Although trawling can lead to these shortcuts in trophic relationships and enhance secondary production, the direct impor- 
tance of the additional food resource for populations of scavengers is considered to be relatively small (Groenewold and Fonds 2000).

Trawling is known to impact the structure and functioning of benthic ecosystems (Alverson et al. 1994; Collie et al. 2000; Hinz et al. 2009; Hiddink et al. 2017). The pressure of constant extraction can damage the maintenance of populations as it impacts recruitment, reproduction and growth of specimens (Stanski et al. 2016). The constant trawling impact on non-commercial species can change the predator-prey relationships due to the loss of biological diversity, disturbance or elimination of local species and can jeopardize the balance of the marine ecosystem (Stanski et al. 2016). Taking into account that surveys had a $\sim 20$ min duration and that commercial trawls last between 2 and $6 \mathrm{~h}$ (Álvarez and Salazar 2010; Marín-Alpízar et al. 2019) an increase in the abundance of hermit crabs in these nets is expected due to mesh plugging and reduction of selectivity (Stanski et al. 2016). According to Marín-Alpízar et al. (2019) trawls for fisheries focused on Solenocera agassizii and Farfantepenaeus brevirostris should have a maximum duration of two hours so that the mesh will not become obstructed and increasing the bycatch. Nevertheless, these authors did not provide information on non-dominant species or small invertebrates present in these two fisheries. Therefore, the possible impact of the suggested two-hour trawls still needs to be investigated.

In order to attain a sustainable and democratic fishery it is indispensable to consider the sustainability of exploited fish stocks, the maintenance of the ecosystem on which the fishery depends, and an effective and responsible management of the fishery (Pacheco-Urpí et al. 2012; Baigún 2013). Due to the decision taken by the Constitutional Court of Costa Rica (Sentencia No 201310540 2013), studies have aimed to assess the fishery and reduce the abundance of the bycatch associated to shrimp trawling fishery at the Pacific coast of Costa Rica (AJDIP/336-2018 2018;
AJDIP/498-2018 2018, Marín-Alpízar et al. 2019). The majority of the results in these studies has not been officially published and do not assess small organisms $(<10 \mathrm{~cm}$ TL) such as gastropods, bivalves and hermit crabs. Therefore, there is a clear gap of information assessing the maintenance of the ecology and ecosystem on which the fishery depends. Considering that more than $45 \%$ of the survey trawls contained hermit crabs, it is imperative to assess the trawling effects on both non-commercial benthic fauna and changes on predator-prey relationships, before insinuating the possibility of obtaining a sustainable fishery. In case that the trawling shrimp fisheries will be reinstalled in Costa Rica, monitoring programs need to be installed to accompany these fisheries, and special attention should be given to the shallow-water fishery bycatch $(<100 \mathrm{~m})$, which should include the identification of hermit crab species and other small invertebrates $(<10 \mathrm{~cm} \mathrm{TL})$.

\section{ACKNOWLEDGEMENTS}

We are grateful to The Rainbow Jewels, S.A., Puntarenas, for their considerable support, which allowed us to monitor the deep-water resources along the Costa Rican Pacific. Thanks go to the captains (Rigo and Esteban 'Mecate'), the crews of the shrimp trawlers Onuva and Sultana, and to René Diers, managing director of the company. We greatly appreciate the support of all the students who helped us with the collection and handling of the samples. The corroboration of hermit crab identification by Manuel Ayón-Parente was greatly appreciated, as well as the help provided by Rita Vargas at the MZUCR collection. Good quality photographs were possible thanks to the donation of photographic equipment to MZUCR by the Spanish Agency for International Development Cooperation (AECID). ISW and FVR are thankful to SINAC-MINAET for approving their 
sampling permits (no. 181-2010-SINAC). Finally, we would like to thank the two anonymous referees: their thoughtful comments and suggestions help to further improve the quality of this contribution.

\section{REFERENCES}

AJDIP/336-2018. 2018. Junta Directiva de INCOPESCA. Evaluación de los porcentajes de exclusión de FACA en la pesca de arrastre de los camarones de profundidad Pinky, Farfantepenaeus brevirostris y Fidel, Solenocera agassizii, utilizando diferentes tamaños de luces de malla y aditamentos (DEP'S, DET'S y doble relinga), en el Océano Pacífico costarricense. https://www.incopesca.go.cr/acerca_incopesca/transparencia_institucional/jerar cas_decisiones/acuerdos/2018/AJDIP-3362018_Aprueba_permiso_investigacion_Cama ron.pdf.

AJDIP/498-2018. 2018. Junta Directiva de INCOPESCA. Estudio de dinámica de población para la pesquería de camarón por buques de arrastre en el Pacífico de Costa Rica. https://www.incopesca.go.cr/acerca_incopes$\mathrm{ca} /$ transparencia_institucional/jerarcas_decisiones/acuerdos/2018/AJDIP-4982018_Aprobacion_realizar_estudio_camaron.pdf.

Álvarez J, Salazar R. 2010. La pesca de arrastre en Costa Rica. San José: Marviva. Soluciones Litográficas. 55 p. http://www.marviva. net/Publicaciones/PESCA_ARRASTRE_ CR.pdf.

Alverson DL, Freeberg MH, Pope JG, MurAwSKI SA. 1994. A global assessment of fisheries bycatch and discards. FAO Fish Tech Pap. 339: 233 p. http://www.fao.org/3/T4890E /T4890E00.htm.

Amador JA, Alfaro EJ, Lizano OG, Magaña VO. 2006. Atmospheric forcing of the eastern tropical Pacific: A review. Prog Oceanogr. 69: 101-142. doi:10.1016/j.pocean.2006.03.007 Arana P, Alvarez-Perez JA, Pezzuto PR. 2009. Deep-sea fisheries off Latin America: an introduction. Lat Am J Aquat Res. 37 (3): 281-284. doi:10.3856/vol37-issue3-fülltext-1

Arana P, Wehrtmann IS, Orellana JC, NielSEN-Muñoz V, Villalobos-Rojas F. 2013. Bycatch associated with fisheries of Heterocarpus vicarius (Costa Rica) and Heterocarpus reedi (Chile) (Decapoda: Pandalidae): A sixyear study (2004-2009). J Crust Biol. 33 (2): 189-209. doi:10.1163/1937240X-00002123

Ayón-PARente M. 2009. Taxonomía, zoogeografía y aspectos ecológicos de los cangrejos ermitaños de la familia Diogenidae (Crustacea: Decapoda: Anomura) del Pacífico mexicano [PhD thesis]. Sinaloa: Universidad Nacional Autónoma de México.

Ayón-Parente M, Hendrickx ME. 2010. Species richness and distribution of hermit crabs of the family Diogenidae (Crustacea: Decapoda: Anomura) in the eastern Pacific. Nauplius. 18: 1-12. http://crustacea.org.br/wpcontent/uploads/2014/02/nauplius v18n1a01.Ayon-ParenteHendrickx.pdf.

Ayón-Parente M, Hendrickx ME. 2012a. Two new species of hermit crabs of the genus Areopaguristes Rahayu \& McLaughlin, 2010 (Crustacea: Anomura: Paguroidea: Diogenidae) from the eastern tropical Pacific. Zootaxa. 3407: 22-36. doi:10.11646/zootaxa. 3407.1 .2

Ayón-PARente M, Hendrickx ME. 2012b. A new species of Pagurus (Crustacea: Decapoda: Paguridae), new records and a redescription of hermit crabs from the Mexican Pacific. Sci Mar. 76 (3): 489-506. doi:10.3989/scimar. 03407.09A

Ayón-Parente M, Hendrickx ME. 2013. Redescription and taxonomic status of Paguristes weddellii (H. Milne Edwards) (Crustacea: Anomura: Paguroidea: Diogenidae) from the eastern Pacific. Zootaxa. 3616 (6): 
587-596. doi:10.11646/zootaxa.3616.6.5

Ayón-Parente M, Hendrickx ME, Lemaitre R. 2015. Redescription and taxonomic status of Paguristes praedator Glassell, 1937 and $P$. oxyophthalmus Holthuis, 1959 (Anomura: Paguroidea: Diogenidae), with an emendation to the diagnosis of the genus Areopaguristes Rahayu \& McLaughlin, 2010. Zootaxa. 3915 (4): 491-509. doi:10.11646/zootaxa.3915.4.2 Ayón-Parente M, Madrid-Vera J. 2009. Nuevos registros y patrón de coloración del cangrejo ermitaño, Stratiotes mclaughlinae (Crustacea: Paguroidea: Diogenidae), del Pacífico mexicano. REVMAR. 37: 43-46.

Ayón-Parente M, Wehrtmann IS. 2019. Description of a new species of Pagurus Fabricius, 1775 (Crustacea: Paguroidea: Paguridae) from the Pacific coast of Costa Rica, Central America, with notes on Pagurus albus (Benedict, 1892). Zootaxa. 4712 (1): 101-113. doi: 10.11646/zootaxa.4712.1.7

BAIGÚN CRM. 2013. Manual para la gestión ambiental de la pesca artesanal y las buenas prácticas pesqueras en la cuenca del río Paraná, Argentina. Buenos Aires: Fundación Humedales/Wetlands International. 77 p.

Ball EE, Haig J. 1974. Hermit crabs from the tropical eastern Pacific. I. Distribution color and natural history of some common shallowwater species. Bull South Cal Acad Sci. 73: 95104. https://scholar.oxy.edu/scas/vol73/iss2/8.

Bensch A, Gianni M, Gréboval D, Sanders J, HJORT A. 2008. Worldwide review of bottom fisheries in the high seas. FAO Fish Aquacult Tech Pap. 522: 1-145.

Branco JO, Freitas Júnior F, ChristofFERSEN ML. 2015. Bycatch fauna of seabob shrimp trawl fisheries from Santa Catarina State, southern Brazil. Biota Neotrop. 15 (2): e20140143. doi:10.1590/1676-06032015014 314

BrifFA M, Bridger D, Biro PA. 2013. How does temperature affect behaviour? Multilevel analysis of plasticity, personality and pre- dictability in hermit crabs. Animal Behav. 86 (1): 47-54. doi:10.1016/j.anbehav.2013.04.009

CAmpos JA. 1986. Fauna de acompañamiento del camarón en el Pacífico de Costa Rica. Rev Biol Trop. 34 (2): 185-197. https://www.revistas.ucr.ac.cr/index.php/rbt/article/view/24226/ 24341.

Clarke TM, Espinoza M, Romero-Chaves R, WEHRTMANN IS. 2018. Assessing the vulnerability of demersal elasmobranchs to a datapoor shrimp trawl fishery in Costa Rica, Eastern Tropical Pacific. Biol Conserv. 217: 321328. doi:10.1016/j.biocon.2017.11.015

Collie JS, Escanero GA, Valentine PC. 2000. Photographic evaluation of the impacts of bottom fishing on benthic epifauna. ICES J Mar Sci. 57: 987-1001. doi:10.1006/jmsc. 2000. 0584

Cortés J, Wehrtmann IS. 2009. Diversity of marine habitats of the Caribbean and Pacific of Costa Rica. In: WehrTmann IS, Cortés J, editors. Marine biodiversity of Costa Rica, Central America. Monographiae Biologicae Vol. 86. Springer Science + Business Media B.V. p. 1-45.

Dumont LFC, D'InCAO F. 2011. By-catch analysis of Argentinean prawn Artemesia longinaris (Decapoda: Penaeidae) in surrounding area of Patos Lagoon, southern Brazil: effects of different rainfall. J Mar Biol Assoc UK. 91 (5): 1059-1072. doi:10.1017/S0025315410001852

ESRI. 2019. ArcGIS. Version 10.7 [software]. [accessed 2019 March 21]. https://esri.com/ es-es/arcgis.

Fransozo A, Mantelatto F LM, Bertini G, Fernandez-Goes LC, Martinelli JM. 1998 Distribution and assemblages of anomuran crustaceans in Ubatuba Bay, North coast of Sao Paulo State, Brazil. Acta Biol Venez. 18 (4): 17-25.

Frameschi IF, ANDrade LS, TAdDEI FG, FranSOZO V, Fernandes-Goés LC. 2014. Assemblage of hermit crabs near coastal islands in southeastern Brazil. Neotrop Biol Conserv. 9 
(1): 9-19.

GILLAND S. 2017. The effects of changes in temperature and salinity on the behavior of the hermit crab Pagurus longicarpus [PhD thesis]. Medford: Tufts University.

Gillett R. 2008. Global study of shrimp fisheries. FAO Fish Tech Pap. 475. 331 p. http://www.fao.org/docrep/011/i0300e/i0300 e00.htm.

Gimenez-Hurtado E, Caridad-Pérez MA, DelGado-Miranda G, Alonso-Domínguez H, Villafuerte-Delgado V. 2016. Comportamiento de la fauna acompañante en la pesca de camarón rosado (Farfantepenaeus notialis) en la Plataforma suroriental de Cuba. Rev electrón Vet. 17 (11): 1-21. https://www.veterinaria. org/revistas/redvet/n111116/111604.pdf.

Gorman D, RAgagnin MN, TuRra A. 2018. Assessing the resilience of hermit crabs to extrinsic and intrinsic environmental change. Estuar Coast Shelf Sci. 214: 25-30. doi:10. 1016/j.ecss.2018.09.003

GROENEWOLD S, FondS M. 2000. Effects on benthic scavengers of discards and damaged benthos produced by the beam-trawl fishery in the southern North Sea. ICES J Mar Sci. 57: 1395-1406. doi:10.1006/jmsc.2000.0914

Gutierrez JD, McDermott JJ. 2004. Hermit crab biocoenoses: a worldwide review of the diversity and natural history of hermit crab associates. J Exp Mar Biol Ecol. 305: 1-128.

KELleHER K. 2005. Discards in the world's marine fisheries. An update. FAO Fish Tech Pap. 470. 131 p.

HAIG J, HoPKINS TS. 1970. The shallow water anomuran crab fauna of Southwestern Baja California, Mexico. San Diego Soc Nat Hist Trans. 16 (2): 13-32. doi:10.5962/bhl.part. 15453

HENDRICKX ME. 1995. Camarones. In: FISCHER W, Krupp F, Schneider W, Sommer C, CARPENTER KE, NIEM VH, editors. Guía FAO para la identificación de especies para los fines de pesca. Pacífico centro-oriental. Vol. I. Plantas e invertebrados. Roma: FAO. p. 417-537.

HeNDRICKX ME, HARVEY AL. 1999. Checklist of anomuran crabs (Crustacea: Decapoda) from Eastern Tropical Pacific. Belg J Zool. 129 (2): 363-389.

Hernáez P, Rombenso A, Pinheiro MA, Simões N. 2012. Population structure and sexual maturity of the calico box crab Hepatus epheliticus Linnaeus (Brachyura, Hepatidae) from Yucatan Peninsula, Mexico. Lat Am J Aquat Res. 40 (2): 480-486. doi:10.3856/vol 40-issue2-fulltext-25

Hinz H, Prieto V, Kaiser MJ. 2009. Trawl disturbance on benthic communities: chronic effects and experimental predictions. Ecol Appl. 19 (3): 761-773. doi:10.1890/08-0351.1 Hiddink JG, Jennings S, Sciberras M, Szostek CL, Hughes KM, Ellis N, AdriaAn D, RijnsDORP AD, MCCONNAUGHEY RA, MAZOR T, et al. 2017. Effects of bottom trawling on seabed biota. Proc Natl Acad Sci USA. 114 (31): 8301-8306. doi:10.1073/pnas.1618858114

Hothorn T, Bretz F, Westfall P. 2008. Simultaneous inference in general parametric models. Biom J. 50 (3): 346-363. doi: 10.1002/ bimj. 200810425

Hothorn T, Hornik K, Zeileis A. 2006. Unbiased recursive partitioning: a conditional inference framework. J Comput Graph Stat. 15 (3): 651-674. doi:10.1198/106186006X 133933

[ITCR] Instituto Tecnológico de Costa Rica. 2014. Atlas digital de Costa Rica 2014. Escuela de Ingeniería Forestal [CD-ROM]. Cartago Costa Rica: Instituto Tecnológico de Costa Rica.

Lemaitre R. 1989. Revision of the genus Parapagurus (Anomura: Paguroidea: Parapaguridae), including redescription of the western Atlantic species. Zool Verhand. 253: 1-106. https://pdfs.semanticscholar.org/c69f/0b48aef 6b159e05d54111ae11f350f84137d.pdf.

LEMAITRE R. 1995. A review of the hermit crabs of the genus Xylopagurus A. Milne Edwards, 
1880 (Crustacea: Decapoda: Paguridae), including descriptions of two new species. Smithson Contrib Zool. 570. 27 p. doi:10. 5479/si.00810282.570.i

Lemaitre R, Alvarez-León R. 1992. Crustáceos decápodos del Pacífico Colombiano: Lista de especies y consideraciones zoogeográficas. An Inst Mar Punta Betín. 21: 33-76. https:// repository.si.edu/bitstream/handle/10088/ 7335/IZ_Lemaitre1992CrustaceosDecapodos DelPacifico.pdf? sequence $=1 \&$ is Allowed $=y$.

Lemaitre R, McLaughlin PA. 1996. Revision of Pylopagurus and Tomopagurus (Crustacea: Anomura: Paguridae), with the description of new genera and species. Part V. Anisopagurus McLaughlin, Manucomplanus McLaughlin and Protoniopagurus new genus. Bull Mar Sci. 59: 89-141. https://pdfs.semanticscholar. org/3b91/1542c02550926bcfe29d46f95ae 9b0941f87.pdf.

Marín-Alpízar B, Mejía Arana F, Pacheco Chaves B, González Rojas M, Alfaro RodRíGuEZ J. 2019. Evaluación de los porcentajes de exclusión de FACA en la pesca de arrastre de los camarones de profundidad pinky Farfantepenaeus brevirostris y fidel Solenocera agassizii utilizando diferentes tamaños de luces de malla, aditamentos (DEP, DET's y doble relinga) y otras mejoras, en el océano Pacífico costarricense. Documento Técnico $\mathrm{N}^{\circ}$ 23. INCOPESCA. 96 p.

McLaughlin PA. 1981a. Revision of Pylopagurus and Tomopagurus (Crustacea: Decapoda: Paguridae), with the descriptions of new genera and species: Part I. Ten new genera of the Parapaguridae and a redescription of Tomopagurus A. Milne Edwards and Bouvier. Bull Mar Sci. 31: 1-30. http://docserver.ingen taconnect.com/deliver/connect/umrsmas/ $00074977 / \mathrm{v} 31 \mathrm{n} 1 / \mathrm{s} 1 . p d f ?$ expires $=1579027406$ $\& \mathrm{id}=0000 \&$ titleid $=10983 \&$ checksum $=07 \mathrm{~A}$ CABF87A99C915DEC82C61B47623BE.

McLaughlin PA. 1981b. Revision of Pylopagurus and Tomopagurus (Crustacea: Decapoda:
Paguridae), with the descriptions of new genera and species: Part II. Rhodochirus McLaughlin and Phimochirus McLaughlin. Bull Mar Sci. 31: 329-365. http://docserver. ingentaconnect.com/deliver/connect/umrs mas $/ 00074977 / \mathrm{v} 31 \mathrm{n} 2 / \mathrm{s} 7 . \mathrm{pdf}$ ?expires $=157902$ $7250 \&$ id $=0000 \&$ titleid $=10983 \&$ checksum $=C$ 46F3265197298BA126289391CFE68EC.

MCLaughlin PA. 1982. Revision of Pylopagurus and Tomopagurus (Crustacea: Decapoda: Paguridae), with the descriptions of new genera and species: Part III. Agaricochirus McLaughlin, and Enallopaguropsis McLaughlin. Bull Mar Sci. 32: 823-855. http://doc server.ingentaconnect.com/deliver/connect/u mrsmas/00074977/v32n4/s2.pdf?expires $=157$ $9027582 \& \mathrm{id}=0000 \&$ titleid $=10983 \&$ check sum $=$ B7926915EF187670AE78B9EF2ADE 9000.

McLaughlin PA, Komai T, Lemaitre R, Rahayu DL. 2010. Annotated checklist of anomuran decapod crustaceans of the world (exclusive of the Kiwaoidea and families Chirostylidae and Galatheidae of the Galatheoidea) Part I, Lithodoidea, Lomisoidea and Paguroidea. Raffles Bull Zool. 23: 5-107.

Meltzer L, Blinick NS, Fleishman AB. 2012. Management implications of the biodiversity and socio-economic impacts of shrimp trawler bycatch in Bahía de Kino, Sonora, México. PLoS One. 7 (6): e35609. doi:10.1371/jour nal.pone.0035609

[MODIS] Moderate Resolution Imaging SpeCTRORADIOMETER. 2019. Greenbelt, MD: Ocean Color Data, NASA OB.DAAC. c1996 - [cited 2018 April 26]. https://oceancolor.gsfc.nasa. gov/data/10.5067/AQUA/MODIS/L3B/SST/ 2014/.

Moran DA, DitTel AI. 1993. Anomuran and Brachyuran crabs of Costa Rica: annotated list of species. Rev Biol Trop. 41 (3): 599-617. https://revistas.ucr.ac.cr/index.php/rbt/article/ view/23978/24129.

Morato T, Watson R, Pitcher T, Pauly D. 2006. 
Fishing down the deep. Fish Fish. 7: 23-33. doi:10.1111/j.1467-2979.2006.00205.x

[NWSCPC] National Weather Service Climate Prediction Center. 2019. Meryland: Cold \& Warm Episodes by Season; c19702019 [accessed 2019 March 2]. National Oceanic and Atmospheric Administration. https://origin.cpc.ncep.noaa.gov/ products/analysis_monitoring/ensostuff/ONI v5.php.

Nielsen-Muñoz V, Quesada-Alpízar MA. 2006. Ambientes marino costeros de Costa Rica. San José: Comisión interdisciplinaria marino costera de la zona económica exclusiva de Costa Rica, CIMAR, CI, TNC. Informe Técnico. 219 p. http://www.ucipfg.com/ Repositorio/BAAP/BAAP06/Publicaciones/ Infome_ambientes_marino_costeros.pdf.

Norse EA, Brooke S, Cheung WL, Clark MR, EkEland I, Froese R, GJERdE KM, HaEdrich RL, Heppell SS, Morato T, et al. 2012. Sustainability of deep-sea fisheries. Mar Policy. 36: 307-320. doi:10.1016/j.marpol.2011.06.008

OKSANEN O, BLANChET FG, Friendly M, KINDT R, Legendre P, McGlinn D, Minchin PR, O'Hara RB, Simpson GL, Solymos P, et al. 2016. Vegan: Community Ecology Package. Version 2.3-5 [R Package http://CRAN.R-project.org/package $=$ vegan].

Pacheco-Urpí O, Salas S, Sierra-Sierra L. 2012. Determination of criteria and indicators for good governance in management for the sustainability of the fishery resources of the Gulf of Nicoya and in particular of the communities of Costa de Pájaros and Manzanillo. Rev Geogr Am Central. 49: 75-102. https:// www.cabdirect.org/cabdirect/abstract/201333 66382.

Polidoro BA, Livingstone SR, CARpenter KE, Hutchinson B, Mast RB, Pilcher N, Sadovy de Mitcheson, Valenti S. 2008. Status of the world's marine species. In: VIÉ, JC, Hilton-Taylor C, Stuart SN, editors. The 2008 Review of The IUCN Red List of Threat- ened Species. Gland: IUCN; [accessed 2019 January 10]. https://www.researchgate.net/ publication/263082397_Status_of_the_ world's_marine_species.

Pretterebner K, Reidel B, Zuschin M S, StaCHOWITSCH M. 2012 Hermit crabs and their symbionts: Reactions to artificially induced anoxia on a sublittoral sediment bottom. J Exp Mar Bio Ecol. 411: 23-33.

Puentes V, Madrid N, Zapata LA. 2007. Catch composition of the deep sea shrimp fishery (Solenocera agassizi Faxon, 1893; Farfantepenaeus californiensis Holmes, 1900 and Farfantepenaeus brevirostris Kingsley, 1878) in the colombian pacific ocean. Gayana. 71 (1): 8495. doi:10.4067/S0717-65382007000100009

Queirolo D, Erzini K, Hurtado CF, Gaete E, SORIGUER MC. 2011. Species composition and bycatches of a new crustacean trawl in Chile. Fish Res. 110: 149-159. doi:10.1016/j.fishres. 2011.04.001

RAmírez-Llodra E, Tyler PA, BAKer MC, Bergstad OA, Clark MR, Escobar E, LeVin LA, Menot L, Rowden AA, Smith CR, VAN Dover CL. 2011. Man and the last great wilderness: human impact on the deep sea. PLoS One. 6 (8): e22588. doi:10.1371/journal.pone.0022588

Ramsay H, Kaiser MJ, Hughes RN. 1996. Changes in hermit crab feeding patterns in response to trawling disturbance. Mar Ecol Prog Ser. 144: 63-72. https:/www.int-res.com/ articles/meps/144/m144p063.pdf.

ROBERTS C. 2007. The unnatural history of the sea. Washington, DC: Island Press.

ROBERTS CM. 2002. Deep impact: the rising toll of fishing in the deep sea. Trends Eco Evol. 17 (5): 242-245. https://mcbi.marine-conservation.org/ what/what_pdfs/Roberts_2002.pdf.

Roberts JJ, Best BD, DunN DC, TREML EA, Halpin PN. 2010. Marine geospatial ecology tools: An integrated framework for ecological geoprocessing with ArcGIS, Python, R, MAT$\mathrm{LAB}$, and $\mathrm{C}++$. Environ Model Softw. 25: 
1197-1207. doi:10.1016/j.envsoft.2010.03.029

SANDERS HL. 1963. Marine benthic diversity: a comparative study. Am Nat. 102 (925): 243 282. https://www.jstor.org/stable/2459027.

Sentencia NO 2013-10540. 2013. Sala Constitucional de la Corte Suprema de Justicia. 7 de agosto del 2013.

[SinAC] Sistema Nacional de Áreas de ConSERVACIÓN. 2008. Gruas II: Propuesta de ordenamiento territorial para la conservación de la biodiversidad de Costa Rica. Vol. 3. Análisis de vacíos en la representatividad e integridad de la biodiversidad marina y costera. San José: Ministerio de Ambiente, Energía y Telecomunicaciones (MINAET). $60 \mathrm{p}$.

SOyKan CU, MoOre JE, Zydelis R, Crowder LB, SAFInA C, LEWISON RL. 2008. Why study bycatch? An introduction to the theme section on fisheries bycatch. Endanger Species Res. 5: 91-102. doi:10.3354/esr00175

Stanski G, Mantelatto FL, Leão-Castilho A. 2016. Hermit crab bycatch fauna (Decapoda, Anomura) off the coast of Santa Catarina State, Brazil: diversity and spatial-temporal distribution. Lat Am J Aquat Res. 44 (3): 546556. doi:10.3856/vol44-issue3-fulltext-13

[TNC] The Nature Conservancy. 2008. Bathymetric and benthic models. Assessment of Marine Ecoregions in Mesoamerica [CDROM]. San José Costa Rica: The Nature Conservancy.

VARGAS R, CORTÉS J. 2004. Biodiversidad marina de Costa Rica: Crustacea: Infraorden Anomura. Rev Biol Trop. 54 (2): 461-488.

Vargas R, Wehrtmann IS. 2009. Decapod crustaceans. In: WeHRTMANN IS, CORTÉS J, editors. Marine biodiversity of Costa Rica, Central America. Monographiae Biologicae Vol. 86. Springer Science + Business Media B.V. p.
209-228.

Villalobos-Rojas F, Azofeifa-Solano JC, CAMACHO-García YE, WehrTmann IS. 2017. Gastropods and bivalves taken as by-catch in the deep-water shrimp trawl-fishery along the Pacific coast of Costa Rica, Central America. Molluscan Res. 37 (3): 175-186. doi:10.1080/ 13235818.2017.1279473

Villalobos-Rojas F, Wehrtmann IS. 2018. Reproductive biology of the commercially exploited kolibri shrimp, Solenocera agassizii (Decapoda: Solenoceridae), from the Pacific coast of Costa Rica, with considerations for its management. Rev Biol Trop. 66 (1): 92-107. doi: 10.15517/rbt.v66i1.33264

Wehrtmann IS, Arana PM, Barriga E, Gracia A, Pezzuto PR. 2012. Deepwater shrimp fisheries in Latin America: a review. Lat Am J Aquat Res. 40 (3): 497-535. doi:103856/vol40 -issue3-fulltext-2

WeHrTMAnN IS, EcheVERría-SÁEnZ S. 2007. Crustacean fauna (Stomatopoda, Decapoda) associated with the deepwater fishery of Heterocarpus vicarius (Decapoda, Pandalidae) along the Pacific coast of Costa Rica. Rev Biol Trop. 55 (1): 121-130. doi: 10.15517/rbt. v55i0.5812

Wehrtmann IS, Nielsen-Muñoz V. 2009. The deepwater fishery along the Pacific coast of Costa Rica, Central America. Lat Am J Aquat Res. 37 (3): 543-554. https://scielo.conicyt.cl/ scielo.php?script $=$ sci_arttext\&pid $=$ S0718560X2009000300019\&lng=es\&tlng=en.

ZAR JH. 1999. Biostatistical analysis. 4th ed. Upper Saddle River: Prentice Hall.

Received: 15 January 2020

Accepted: 24 April 2020 
